\title{
Effect of Bacterial Content and Somatic Cell Count on Sheep Milk Quality in Kosovo
}

\author{
Hysen Bytyqi ${ }^{{ }^{*}}$, Hajrip Mehmeti ${ }^{1}$, Idriz Vehapi ${ }^{1}$, Fillojeta Rrustemaj ${ }^{2}$, Ibrahim Mehmeti ${ }^{3}$ \\ ${ }^{1}$ Faculty of Agriculture and Veterinary, University of Prishtina, Prishtina, Kosovo; ${ }^{2}$ Kosovo Veterinary and Food Agency (AVUK), \\ Prishtina, Kosovo; ${ }^{3}$ Norwegian University of Life Sciences (UMB), Ås, Norway. \\ Email: "hysen.bytyqi@uni-pr.edu
}

Received February $27^{\text {th }}, 2013$; revised March $27^{\text {th }}, 2013$; April $4^{\text {th }}, 2013$

Copyright (C) 2013 Hysen Bytyqi et al. This is an open access article distributed under the Creative Commons Attribution License, which permits unrestricted use, distribution, and reproduction in any medium, provided the original work is properly cited.

\begin{abstract}
The main objective of this study was to analyze the effect of bacterial content (CFU) and somatic cell count (SCC) in milk quality in sheep (Ovis aries) farms according to the existing standards for fresh milk quality in Kosovo. A total of 2256 milk test day records from 379 Bardhoka (BAR), Sharri sheep (SHA), Kosovo sheep (KOS) and Balusha (BAL) ewes in eight herds across the country were collected and analyzed through a period April-October 2010. The general linear model and Duncan's test were used to analyze the effect of different variables on presence of CFU and SCC in fresh milk. The effect of all variables was considered as a fixed. The overall results show that farm $(\mathrm{P}<0.0410)$, breed $(\mathrm{P}<0.0076)$, month of the year $(\mathrm{P}<0.0041)$ and the lactation number $(\mathrm{P}<0.0422)$, respectively, had a significant effect on presence of SCC. For CFU farm $(\mathrm{P}<0.0001)$, and month of the year $(\mathrm{P}<0.0064)$ had shown the significant effects, while the lactation number $(\mathrm{P}<0.0422)$ and breed $(\mathrm{P}<0.0076)$, represented no effect. According to the existing legislation in regard to the quality of fresh milk, there was substantial variation between farms ranging from 1211.17 to 6425.76 CFU/mL and 846.07 to $2043.15 \mathrm{SCC} / \mathrm{mL}$ milk, respectively. Although the rate of fresh milk contamination with SCC tends to be relatively low compare with CFU, by all means both variables should not be underestimated bearing in mind that a high rate of them on fresh milk are negatively correlated with farmer's profit, consumer food safety and overall animal health.
\end{abstract}

Keywords: Fresh Milk; Bacteria Content; Somatic Cell; Milk Quality Standards

\section{Introduction}

Milk presents, one of the main items in human nutrition, where its biological and chemical content, represents a suitable environment for the development of microorganisms, as well. Milk containing a low number of microorganisms, somatic cells and residues (antibiotics, pesticides, and hormones), in terms of hygiene is recognized as quality milk. Milk which is synthesized in specialized cells of mammary gland is virtually sterile when secreted into the alveoli [1]. However, microbial contamination can occur from three main sources [2], from within the udder, the outside and during milk handling. Sources of contamination are: Living sources (animals, humans, insects, etc.), non-living sources (bedding, faeces, feed, etc.), equipments and storage facilities (milking machines, handling equipment, etc.). The bacteria that most commonly reside within the sheep udder and that

\footnotetext{
"Corresponding author.
}

can trigger mastitis and other health problems belong to different types: Staphylococcus aurous; Streptococcus spp. (Streptococcus uberis, Streptococcus agalactiae, Streptococcus dysgalactie); Coliphorm group; Pseudomonas (Cepacia burkholderia, Pseudomonas aeruginosae). Besides these bacteria within the sheep can be found mushrooms and some mycoplasma species, which trigger sub-clinical mastitis, as well. SCC's are cellular elements that arrive by the organism in the milk of animals and that lower amount of them in milk represent the normal situation. Knowing that SCC presents heath udder and body indicator, their growth in milk is indication that we are dealing with unsanitary milk and weakened the animal health. This also is the reason that SCC represents one of the parameters for determining the quality of milk. However, there are known some physiological phases here SCC rate is higher as in: colostrum, oestrus, lactation phase, age, dry period, breed, season of year and stress, farm management. The large number of SCC induces changes in milk quality and its loss in pro- 
ductivity [3]. Recently, [4] has proposed three categories of sheep milk sanitation: Good milk that contains $(\mathrm{SCC}<$ 500,000); Average milk containing (SCC between 500,000 and 1,000,000), infected milk (SCC > 1,000,000). The threshold or limit which determines the number of SCC in milk is not clearly defined. The number of somatic cells that represents a healthy udder can be up to $1,600,000 \mathrm{SCC} / \mathrm{mL}$ milk [5]. However, some authors $[6,7]$ have confirmed that threshold or limit the number of somatic cells to a healthy udder gland should not exceed over 250,000 SCC/mL milk. Most of the quantity of sheep's milk produced in the Kosovo is turned into cheese, and is rarely consumed as fresh milk, therefore, the quality of the sheep milk should refer to its ability to be transformed into high-quality products.

The presence of a large number of microorganisms in milk shows a sick animal, high temperature and inadequate conditions of storage and manipulation of milk. So the total number of microorganisms in milk represents the most reliable indicator of its hygiene. However, when interpreting the results, we must be careful that the milk which contains a smaller number of bacteria, does not mean that it is always hygienic milk, it may contain pathogenic microorganisms [8] as they are causes Tuberculosis and Brucellosis [9]. Many microorganisms that are present in milk are beneficial to its transformation into cheese (Lactobacillus spp., Lactococcus spp., Streptococcus spp.). However, others can cause serious human diseases (Salmonella spp., Listeria spp., Brucella spp., etc.), and can cause serious problems in the maturation of cheese (Enteriobactericeae, Coliforms, Psychrotrophs).

The main objective of this research was to study the impact of bacterial content $(\mathrm{CFU} / \mathrm{mL})$ and somatic cells $(\mathrm{SCC} / \mathrm{mL})$ in fresh milk quality in some sheep farms based on existing standards and derive valuable recommendations for the sheep dairy industry in Kosovo.

\section{Material and Methods}

This study included a total of 2256 milk test day records from 379 BAR, SHA, KOS and BAL ewes in eight herds across the country were collected and analyzed through a period April-October 2010, in Kosovo. For data recording identification cards containing: identification number, lactation phase, breed, sample number, date of birth, date of lambing, milk produced, etc., were used. The lack of experience in recording and other reasons had a number of extreme data that are excluded from the analysis in this research. Fresh milk samples were obtained using standard A4 method according to the International Committee for the registration of animal [10]. Milk samples were obtained in $40-50 \mathrm{ml}$ quantity in both milking, in the evening and morning and stored in sterile test tubes. For storage of samples for a longer time AZIDOL preservative (sodium acid) was used, then inserted into the mobile refrigerator at temperature $4^{\circ} \mathrm{C}$ and were transferred to the laboratory for analysis. For determination of CFU and SCC BactoScan and FossomaticMinor (Foss) devices, respectively were used. The results obtained were compared with Administrative Instruction [11], determining the standards for quality of sheep fresh milk for CFU, while for SCC, standards proposed by [4] were used (Table 1).

All breeds are used as triple purpose sheep with specific emphasises to milk and meat. Usually, lambing is seasonal and takes place in a period January-February, while ewes are milked from April to September (after weaning time). During the winter when the sheep are kept inside, the food is provided mainly hay and grain mixture of wheat and corn. Stables are old buildings, without any adequate plan and do not meet hygienic parameters. Low investments have been made to set up milking and processing facilities.

Statistical analysis: Statistical analyzes were performed using JMP-starter package business unit of SAS program [12] by Proc-GLM procedure (General Linear Model). Generally, to asses, the influence of independent variables with potential effect on CFU and SCC in fresh milk was used fixed effect models with a dependent variable. Differences between the averages of different variables were tested with Duncan's test. All effects were considered fixed variables.

\section{Results}

In Table 2, the least squares means, the standard deviation and analysis of variance for the impact of the farm on CFU in fresh milk were presented. Results indicate large variations between farms involved in the experiment $(\mathrm{P}<0.0001)$, thus clearly favoring farm 5 with a smaller number of bacterial content in fresh milk $(\mathrm{CFU}=$ 1211.17), followed by farms, $8,7,2$ and 1 with bacterial load $(\mathrm{CFU}=1561.13),(\mathrm{CFU}=1844.18),(\mathrm{CFU}=$ $1921.55)$ and $(\mathrm{CFU}=1942.20)$.

The highest number of bacterial load was recorded at the farm $4(\mathrm{CFU}=6425.76)$, followed by farm 3 , and 6 with bacterial load $(\mathrm{CFU}=5953.38)$ and $(\mathrm{CFU}=$ 3558.82).

In Table 3, the least squares means, the standard deviation and analysis of variance for the impact of the

Table 1. Milk quality standard in Kosovo (CFU/mL and $\mathrm{SCC} / \mathrm{mL}$ in milk).

\begin{tabular}{cccc}
\hline Standard & $\begin{array}{c}\text { Class Extra } \\
\text { (good milk quality) }\end{array}$ & $\begin{array}{c}\text { Class I and II } \\
\text { (average milk quality) }\end{array}$ & $\begin{array}{c}\text { Poor milk } \\
\text { quality }\end{array}$ \\
\hline $\mathrm{CFU} / \mathrm{mL}$ & $<500,000$ & $<1,000,000,>500,000$ & $>1,500,000$ \\
$\mathrm{SCC} / \mathrm{mL}$ & $<500,000$ & $<1,000,000$ & $>1,000,000$ \\
\hline
\end{tabular}


Table 2. Influence of different farm managementon on bacterial content (CFU/ml) in fresh sheep milk.

\begin{tabular}{|c|c|c|c|}
\hline \multirow[t]{2}{*}{ Effects } & \multicolumn{3}{|c|}{ Bacterial content $(\mathrm{CFU} / \mathrm{ml})$} \\
\hline & $\mathrm{N}$ & LSM & SDEV \\
\hline \multicolumn{4}{|c|}{ Effect of farm on bacterial content $(\mathrm{CFU} / \mathrm{mL})$} \\
\hline Farm 1 & 55 & $1942.20^{\mathrm{c}}$ & 823.5 \\
\hline Farm 2 & 54 & $1921.55^{\mathrm{c}}$ & 760.9 \\
\hline Farm 3 & 48 & $5953.38^{\mathrm{a}}$ & 1445.8 \\
\hline Farm 4 & 33 & $6425.76^{\mathrm{ab}}$ & 1163.9 \\
\hline Farm 5 & 46 & $1211.17^{\mathrm{c}}$ & 388.8 \\
\hline Farm 6 & 54 & $3558.82^{\mathrm{bc}}$ & 1119.9 \\
\hline Farm 7 & 49 & $1844.18^{\mathrm{c}}$ & 779.0 \\
\hline Farm 8 & 37 & $1561.13^{\mathrm{c}}$ & 1022.6 \\
\hline Analysis of variance & $D f$ & \multicolumn{2}{|c|}{$\operatorname{Pr}>F$} \\
\hline Effect of farm $(\mathrm{CFU} / \mathrm{mL})$ & 7 & \multicolumn{2}{|c|}{0.0001} \\
\hline
\end{tabular}

Number of animals per farm (N); Least square means (LSM); Standard deviation (SD); Analyses of variance ( $\mathrm{Pr}>\mathrm{F})$; Degree of freedom ( $D f)$.

Table 3. Influence of different farm managementon on somatic cell count $(\mathrm{SCC} / \mathrm{mL})$ in fresh sheep milk.

\begin{tabular}{cccc}
\hline Effects & \multicolumn{4}{c}{ Somatic cell count $(\mathrm{SCC} / \mathrm{mL})$} \\
\hline & $\mathrm{N}$ & LSM & SDEV \\
\hline Effect of farm on somatic cell count $(\mathrm{SCC} / \mathrm{mL})$ \\
Farm 1 & 55 & $846.07^{\mathrm{c}}$ & 371.63 \\
Farm 2 & 54 & $812.33^{\mathrm{bc}}$ & 305.77 \\
Farm 3 & 48 & $2003.89^{\mathrm{a}}$ & 504.91 \\
Farm 4 & 33 & $2043.15^{\mathrm{ab}}$ & 453.16 \\
Farm 5 & 46 & $977.39^{\mathrm{bc}}$ & 264.90 \\
Farm 6 & 54 & $1585.73^{\mathrm{abc}}$ & 378.85 \\
Farm 7 & 49 & $1610.71^{\mathrm{abc}}$ & 673.14 \\
Farm 8 & 37 & $1959.64^{\mathrm{a}}$ & 233.22 \\
Analysis of variance & $D f$ & \multicolumn{3}{c}{ Pr $>$ F } \\
Effect of farm (SCC/mL) & 7 & \multicolumn{2}{c}{0.0410} \\
\hline
\end{tabular}

Number of animals per farm (N); Least square means (LSM); Standard deviation (SD); Analyses of variance ( $\operatorname{Pr}>\mathrm{F})$; Degree of freedom ( $D f)$.

farm on SCC in fresh milk were presented. For SCC, the significant variations were shown between farms involved $(\mathrm{P}<0.0410)$. The differences ranged from farm 2 with smaller somatic cells $(\mathrm{SCC}=812.33)$ and farm 4 with the highest $(\mathrm{SCC}=2043.15)$ followed from farm 3 $(\mathrm{SCC}=2003.89)$, farm $8(\mathrm{SCC}=1959.64)$ and farm 7 $(\mathrm{SCC}=1610.71)$, respectively.
Table 4 presents the results of influence of different sheep breed on CFU. For CFU, results showed no significant effect among different breeds $(\mathrm{P}<0.0760)$.

Smallest CFU per $\mathrm{mL}$ of milk were depicted by SHA $(\mathrm{CFU}=1680.88)$ followed by $\mathrm{BAL}(\mathrm{CFU}=1933.46)$ KOS breed $(\mathrm{CFU}=2184.59)$ and BAR $(\mathrm{CFU}=6196.73)$.

Table 5 presents the results of influence of different sheep breed on CFU. For SCC, the results obtained from laboratory show a large variations between four breeds involved in research $(\mathrm{P}<0.0076)$, favouring BAL breed with a smaller number of somatic cells $(\mathrm{SCC}=833.42)$, followed by KOS $(\mathrm{SCC}=1208.14)$, while the highest number of SCC in fresh milk was registered to BAR $(\mathrm{SCC}=2027.09)$ followed by SHA $(\mathrm{SCC}=1843.33)$.

In Figures 1 and 2, the result of CFU and SCC in fresh milk to sheep per month was depicted. During the whole period, the CFU content and SCC were high and significantly different, $\mathrm{P}<0.0064$ and $\mathrm{P}<0.0041$, respectively.

Table 4. Influence of different sheep breed on bacterial content (CFU/ml) in fresh sheep milk.

\begin{tabular}{|c|c|c|c|}
\hline \multirow[t]{2}{*}{ Effects } & \multicolumn{3}{|c|}{ Bacterial content $(\mathrm{CFU} / \mathrm{ml})(\mathrm{SCC} / \mathrm{mL})$} \\
\hline & $\mathrm{N}$ & LSM & SDEV \\
\hline \multicolumn{4}{|c|}{ Effect of breed on bacterial content $(\mathrm{CFU} / \mathrm{mL})$} \\
\hline BAL & 81 & $1933.46^{\mathrm{b}}$ & 563.08 \\
\hline BAR & 100 & $6196.73^{\mathrm{a}}$ & 908.73 \\
\hline KOS & 86 & $2184.59^{\mathrm{b}}$ & 540.67 \\
\hline SHA & 109 & $1680.88^{\mathrm{b}}$ & 664.32 \\
\hline Analysis of variance & Df & \multicolumn{2}{|c|}{$\operatorname{Pr}>F$} \\
\hline $\begin{array}{l}\text { Effect of breed } \\
\quad(\mathrm{CFU} / \mathrm{mL})\end{array}$ & 3 & \multicolumn{2}{|c|}{0.0760} \\
\hline
\end{tabular}

Number of animals per breed (N); Least square means (LSM); Standard deviation (SD); Analyses of variance ( $\mathrm{Pr}>\mathrm{F})$; Degree of freedom $(D f)$.

Table 5. Influence of different sheep breed on and somatic cell count $(\mathrm{SCC} / \mathrm{mL})$ in fresh sheep milk.

\begin{tabular}{|c|c|c|c|}
\hline \multirow[t]{2}{*}{ Effects } & \multicolumn{3}{|c|}{ Somatic cell count $(\mathrm{SCC} / \mathrm{mL})$} \\
\hline & $\mathrm{N}$ & LSM & SDEV \\
\hline \multicolumn{4}{|c|}{ Effect of breed on somatic cell count $(\mathrm{SCC} / \mathrm{mL})$} \\
\hline BAL & 81 & $833.42^{\mathrm{c}}$ & 265.32 \\
\hline BAR & 100 & $2027.09^{\mathrm{a}}$ & 277.11 \\
\hline KOS & 86 & $1208.14^{\mathrm{bc}}$ & 241.36 \\
\hline SHA & 109 & $1843.33^{\mathrm{ab}}$ & 283.63 \\
\hline Analysis of variance & $D f$ & \multicolumn{2}{|c|}{$\operatorname{Pr}>F$} \\
\hline Effect of breed $(\mathrm{SCC} / \mathrm{mL})$ & 3 & \multicolumn{2}{|c|}{0.0076} \\
\hline
\end{tabular}

Number of animals per breed (N); Least square means (LSM); Standard deviation (SD); Analyses of variance $(\operatorname{Pr}>\mathrm{F})$, Degree of freedom $(D f)$. 


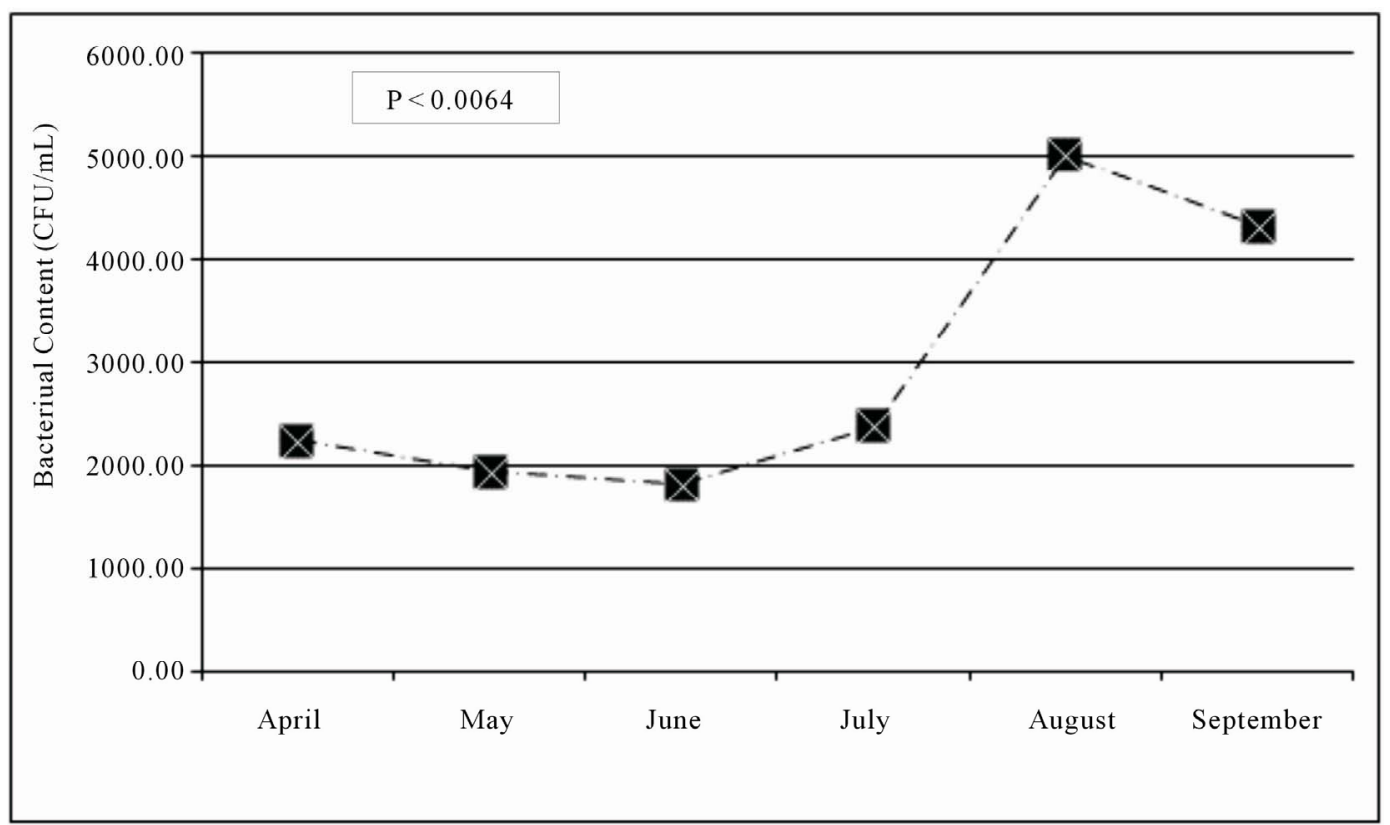

Figure 1. Bacterial content $(\mathrm{CFU} / \mathrm{mL})$ per month in fresh sheep milk.

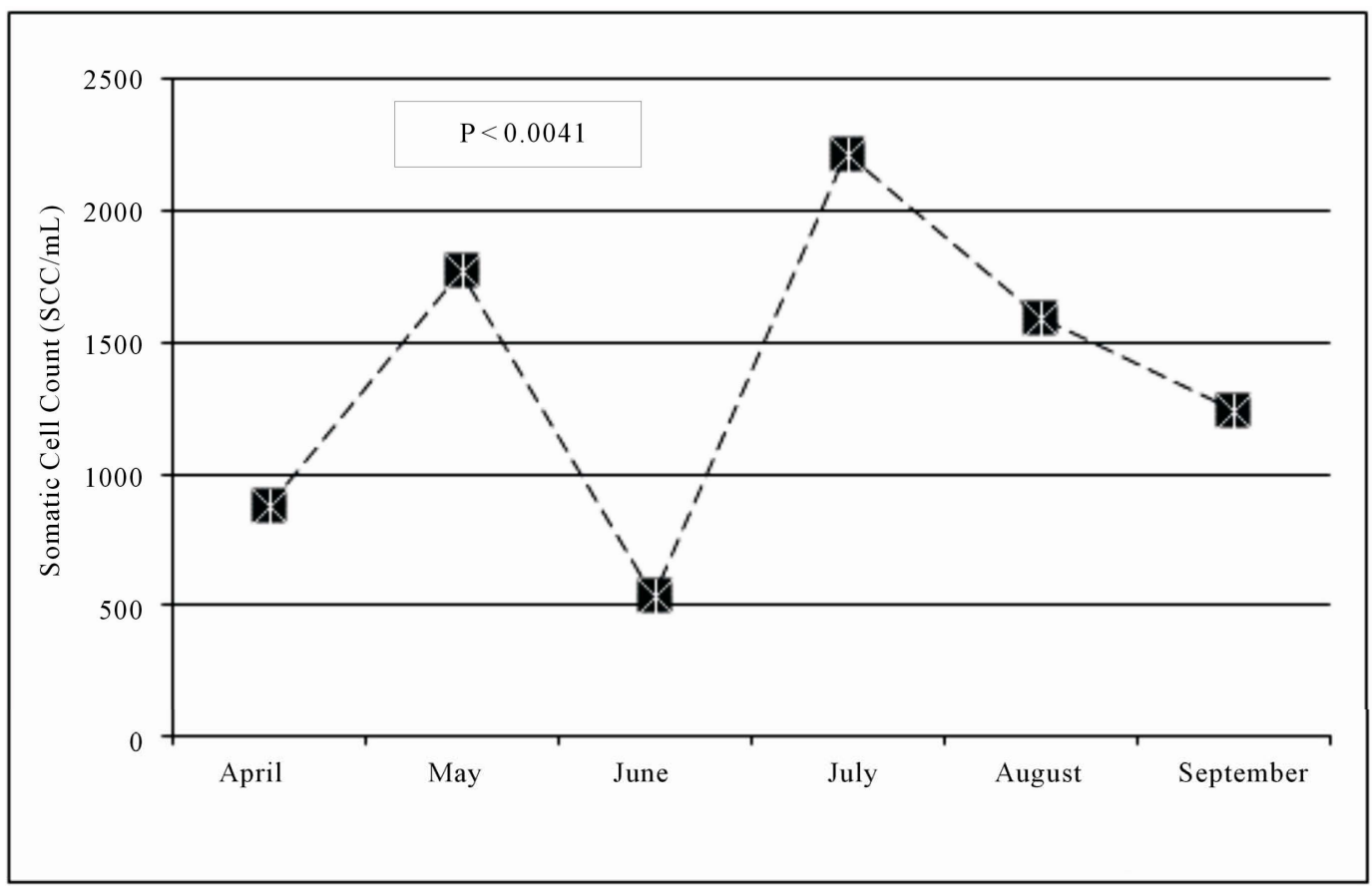

Figure 2. Somatic cell content (SCC/mL) per month in fresh sheep milk.

In April, this rate was about $(\mathrm{CFU}=2000.00)$, in May and June falls under $(\mathrm{CFU}<2000.00)$. CFU starts to increases in July (CFU $>2000.00)$ and a larger increase was depicted in August CFU $\approx 5000.00$ ) and in September (CFU > 4000.00), respectively.

The lowest SCC rate was indicated in the April (SCC $\approx 800.00$ ) and June (SCC $\approx 500.00$ ), followed by September ( $\mathrm{SCC} \approx 1200.00)$, August ( $\mathrm{SCC} \approx 1500.00$ ), and May $(\mathrm{SCC} \approx 1700.00)$. The highest rate of SCC was shown in July (SCC < 2000.00).

The influence of lactation on CFU content was shown in Table 6. Results obtained showed a large variation between lactations $(\mathrm{P}<0.0422)$ for SCC while for CFU differences were not significant $(\mathrm{P}<0.6093)$. Milk from the sheep in the second lactation tended to have low bacteria $(\mathrm{CFU}=2307.21)$, followed by the third lactation $(\mathrm{CFU}=3251.25)$, fourth $(\mathrm{CFU}=2805.62)$, the sixth lactation $(\mathrm{CFU}=2725.33)$ and first lactation $(\mathrm{CFU}=$ 
2642.7). The highest bacterial content was indicated in the fifth lactation $(\mathrm{CFU}=4404.84)$.

The influence of lactation on SCC content was shown in Table 7. The lowest rate for SCC was shown to the milk deriving from the sheep in the 1st lactation $(\mathrm{SCC}=$ 253.00), followed by 5th lactation $(\mathrm{SCC}=1850.77)$, and 3 rd $(\mathrm{SCC}=1594.81)$. Milk from the sheep in 6th lactation and tend to be highly contaminated by SCC ( SCC $=$ 1992.67).

\section{Discussion}

Based on results obtained, it is shown that both, CFU and

Table 6. Influence of lactation on bacterial content (CFU/ml) in fresh sheep milk.

\begin{tabular}{|c|c|c|c|}
\hline \multirow[t]{2}{*}{ Effects } & \multicolumn{3}{|c|}{ Bacterial content (CFU/ml) (in 000) } \\
\hline & $\mathrm{N}$ & LSM & SDEV \\
\hline \multicolumn{4}{|c|}{ Effect of lactation on bacterial content $(\mathrm{CFU} / \mathrm{mL})$} \\
\hline Lactation 1st & 77 & $2642.75^{\mathrm{a}}$ & 739.6 \\
\hline Lactation 2nd & 89 & $2307.21^{\mathrm{a}}$ & 694.1 \\
\hline Lactation 3rd & 94 & $3251.25^{\mathrm{a}}$ & 993.9 \\
\hline Lactation 4th & 47 & $2805.62^{\mathrm{a}}$ & 763.6 \\
\hline Lactation 5 th & 39 & $4404.84^{\mathrm{a}}$ & 950.6 \\
\hline$\leq$ Lactation 6th & 30 & $2725.33^{\mathrm{a}}$ & 2527.7 \\
\hline Analysis of variance & $D f$ & \multicolumn{2}{|c|}{$\operatorname{Pr}>F$} \\
\hline Effect of lactation $(\mathrm{CFU} / \mathrm{mL})$ & 5 & \multicolumn{2}{|c|}{0.6093} \\
\hline
\end{tabular}

Number of animals per lactation (N); Least square means (LSM); Standard deviation (SD); Analyses of variance ( $\mathrm{Pr}>\mathrm{F})$; Degree of freedom $(D f)$.

Table 7. Influence of lactation on somatic cell count (SCC/ $\mathrm{mL}$ ) in fresh sheep milk.

\begin{tabular}{|c|c|c|c|}
\hline \multirow[t]{2}{*}{ Effects } & \multicolumn{3}{|c|}{ Somatic cell count $(\mathrm{SCC} / \mathrm{mL})($ in 000$)$} \\
\hline & $\mathrm{N}$ & LSM & SDEV \\
\hline
\end{tabular}

Effect of breed on somatic cell count $(\mathrm{SCC} / \mathrm{mL})$

\begin{tabular}{cccc} 
Lactation 1st & 77 & $253.00^{\mathrm{ab}}$ & $\cdot$ \\
Lactation 2nd & 89 & $704.33^{\mathrm{b}}$ & 315.3 \\
Lactation 3rd & 94 & $1594.81^{\mathrm{abc}}$ & 336.8 \\
Lactation 4th & 47 & $1274.24^{\mathrm{ab}}$ & 197.0 \\
Lactation 5th & 39 & $1850.77^{\mathrm{a}}$ & 282.8 \\
SLactation 6th & 30 & $1992.67^{\mathrm{ab}}$ & 1187.7 \\
Analysis of variance & $D f$ & \multicolumn{2}{c}{$\operatorname{Pr}>\mathrm{F}$} \\
Effect of lactation (SCC/mL) & 5 & \multicolumn{2}{c}{0.0422} \\
\hline
\end{tabular}

Number of animals per lactation (N); Least square means (LSM); Standard deviation (SD); Analyses of variance ( $\operatorname{Pr}>\mathrm{F})$; Degree of freedom $(D f)$.
SCC content in fresh milk is high, compared with standards, which are in force in Kosovo. As in the study of [3], in this research there was observed a high impact of management between farms. The breed had the significant effect on SCC showing large variations between BAR, BAL SHA, and KOS sheep. Numerical differences were shown for presence of CFU in milk for different breeds that as in the study of $[13,14]$ is characterized mainly by the different farm management system (poor farm handling, pasture systems, etc.). Another factor that affects the CFU and SCC burden were lactation number and month of the year, considering older lactations as a potential contamination factor, especially in regard to SCC. Our results match with research done by [7] indicating lower SCC to Italian sheep in first lactation $(57.000 \mathrm{SCC} / \mathrm{mL})$ milk, whereas with increasing age or lactation increases the number of SCC. It is a concern that if sheep farms continue to produce milk with low quality, as indicated by this study, in particularly when the Kosovo sheep dairy chain has to apply EU regulations, the farmers will not be able to sell their milk legally (in dairies, milk processors, etc.). Therefore, the only way to benefit from the farms will remain to sell the milk products illegally (open market, home-processed, etc.) where the sanitary control and food-safety mechanism are not in place. As in the study of [15], the presence of SCC in milk is a parameter that should not be underestimated, giving the fact that increased SCC, besides affecting the quality of milk, they are directly associated with the animal health status and causes major economic losses in our farms. Due to confounding effect of breed and farm, our results do not fully match the hypothesis indicating breeds with the highest milk production tend to present high SCC $[16,17]$. Obviously, the implementation of best farm management practices and milk quality standards (SCC and CFU), investment in the farm infrastructure, the farmers' training, i.e., on the use of California Mastitis Test (CMT), providing qualitative data for CFU and SCC are key factors for improving the quality of fresh milk, animal health and increase profitability of farmers in Kosovo. In order to avoid increase "illegal" market/trade of sheep milk products, the implementation of milk quality standards (SCC and CFU) should be developed parallel with investment in the sheep farm infrastructure. Putting into force and implementation of standards for assessing the hygiene of milk based on the content of SCC $(>500,000$ per ml milk) and California Mastitis Test using (CMT) will have a positive impact both in the quality of milk, as well as the flock health. This research, among the first ones from this field in the country, opens the possibility to access and avoid potential routes of sheep milk contamination with $\mathrm{CFU}$ and SCC, improves animal health, consumer safety and profitability of the farmer (time avoiding infections, pre- 
miums, bonuses, treatment time, etc.).

\section{Conclusions}

The number of bacterial content and somatic cell count in fresh milk, in Kosovo was very high and urgent steps must be taken to improve factors associated with milk quality (i.e., farm management, animal structure, milking and processing devices, etc.). Data from our study include almost half of contamination means and the effects of milk by CFU and SCC, study and exploration of other factors, as: the impact of stress, types of microorganisms, pathogenic effect, and other factors will provide a better-quality picture and food-safety standard for sheep milk and its products.

Providing quality milk in terms of hygiene will enable producers and processors of dairy sheep in Kosovo, to be able to check the health of the flock, process and offer milk products with high quality to customers, increase overall profitability and this will be able to compete against similar products from imports.

\section{REFERENCES}

[1] A. Tolle, "The Microflora of the Udder. In: Factors Influencing the Bacteriological Quality of Raw Milk," International Dairy Federation Bulletin, Document 120, 1980, 4 p.

[2] J. A. Bramley and H. C. Mckinnon, "The Microbiology of Raw Milk," In: R. K. Robinsson, Ed., Dairy Microbiology, Vol. 1, Elsevier Applied Sciences, London, 1990, pp. 163-208.

[3] R. H. Whay, J. C. D. Main, E. L. Green and F. J. A. Webster, "Assessment of the Welfare of Dairy Cattle Using Animal-Based Measurements: Direct Observations and Investigation of Farm Records," Veterinary Record, Vol. 153, 2003, pp. 197-202. doi:10.1136/vr.153.7.197

[4] C. Gonzalo, A. Tardáguila, A. Ariznabarreta, M. Romeo, V. Monitoro, D. M. Pérez-Guzmán and C. J. Y. Marco, "Recuentos de Células Somáticas en el Ganado Ovino Lechero y Estrategias de Control," Situacion en España, Ovis, Vol. 66, 2000, pp. 21-27.

[5] J. Ten Hague, "Milk Quality Assurance Program Lead/ OMAFRA," 2002.

[6] A. Pengov, "The Role of Coagulase-Negative Staphylococcus spp. and Associated Somatic Cell Counts in the Ovine Mammary Gland,” Journal of Dairy Science, Vol.
84 , No. 3, 2001, pp. 572-574. doi: 10.3168/jds.S0022-0302(01)74509-2

[7] I. P. Menzies and Z. S. Ramanoon, "Mastitis of Sheep and Goats," The Veterinary Clinics of North America: Food Animal Practice, Vol. 17, 2001, pp. 333-358.

[8] M. B. Jayarao and R. D. Wolfgang, "Bulk-Tank Milk Analysis. A Useful Tool for Improving Milk Quality and Flock Udder Health," The Veterinary Clinics of North America: Food Animal Practice, Vol. 19, No. 1, 2003, pp. 75-92. doi:10.1016/S0749-0720(02)00075-0

[9] International Committee for Animal Recording, "International Regulations for Milk Recording in Sheep," Institut de l'élevage, Department Génétique ei Contrôle des Performances, Paris, 2003.

[10] H. Benson, "Microbiological Applications," 7th Edition, Pasadena City College, Pasadena, 1999, p. 6.

[11] Ministry of Agriculture, Forestry and Rural Development, "Administrative Instruction MA-No. 20/2006 on Quality Standards and Grade of Fresh Milk," 2006.

[12] J. Sall, A. Lehman, L. Creighton and JMP Start Statistics, "A Guide to Statistics and Data Analysis Using JMP and JMP in Software," 3rd Edition, SAS Institute, Cary, 2004, $491 \mathrm{p}$.

[13] H. Bytyqi, S. Bigler, S. Muji, A. Jahja and U. Zaugg, "Survey on Raw Milk Quality in Kosovo," Food and Nutrition Sciences, Vol. 2, 2011, pp. 414-421. doi:10.4236/fns.2011.25058

[14] J. J. Goldberg, E. E. Wildman, W. J. Pankey, R. J. Kunkel, B. D. Howard and M. B. Murphy, "The Influence of Intensively Managed Rotational Grazing, Traditional Continuous Grazing, and Confinement Housing on Bulk Tank Milk Quality and Udder Health," Journal of Dairy Science, Vol. 75, No. 1, 1992, pp. 96-104. doi:10.3168/jds.S0022-0302(92)77743-1

[15] H. Bytyqi, U. Zaugg, K. Sherifi and A. Hamidi, "Influence of Management and Physiological Factors on Somatic Cell Count in Raw Cow Milk in Kosova," Veterinarski Arkiv, Vol. 80, No. 2, 2010, pp. 173-183.

[16] V. Riggio, R. Finocchiaro, J. B. C. H. M. van Kaam, B. Portolano and H. Bovenhuis, "Genetic Parameters for Milk Somatic Cell Score and Relationships with Production Traits in Primiparous Dairy Sheep," Journal of Dairy Science, Vol. 90, No. 4, 2007, pp. 1998-2003. doi: $10.3168 /$ jds.2006-309

[17] D. Bergonier, R. de Cremoux, R. Rupp, G. Lagriffoul and X. Berthelot, "Mastitis of Dairy Small Ruminants," Veterinary Research, Vol. 34, No. 5, 2003, pp. 689-716. doi:10.1051/vetres:2003030 